\title{
Investigating Students' Perception on Asynchronous Online Language Learning during COVID-19 Pandemic: An Exploratory Study
}

\author{
Zakie Mahri Prasojo \\ 1710631060186@student.unsika.ac.id \\ Mansyur Srisudarso \\ mansyur.srisudarso@staff.unsika.ac.id \\ University of Singaperbangsa Karawang
}

\begin{abstract}
The aims of this study are to investigate the perceptions of two vocational high school students majoring Animation and Accounting about asynchronous online learning during pandemic and how they overcome the challenges faced. This study used qualitative exploratory research design by conducting observation, interview and documentation to get rich data of the subject under focus. Moreover, the researcher used thematic analysis to analyse the data collected by following six steps proposed by Braun et al. (2019). The findings showed that asynchronous online learning strategies seemed to not fit the participants. The students more preferred learning that is conducted synchronously which for some students is perceived as a burden as they have to deal with the problem of internet data. Other findings also indicated that students who still had problem with material given were likely to have discussion with other students as an effort to overcome one of the challenges faced.
\end{abstract}

Keywords: Students' Perceptions; Asynchronous Online Learning; Distant Learning in Pandemic

\section{INTRODUCTION}

COVID-19 was declared as global emergency by the World Health Organization (WHO) on January 30, 2020, and a global pandemic on March 11, 2020. COVID19 currently affects 213 countries and territories (WHO, 2020). As a result of COVID-19, numerous countries have implemented strong social separation measures as well as a lockdown policy. In order to avoid the spread of the disease, the Indonesian government has restrained community mobilization and continues to promote a work-from-home, study-from-home, and worship-from-home agenda. Since March 14th, 2020, schools and higher education institutions (HEIs) in Indonesia have been temporarily shuttered. In order to fulfillment the right of students to get educational services during an emergency the spread of COVID-19, the learning process is carried out through the implementation of Learning from Home (LFH) as follows listed in the Ministry of Education and Culture circular letter Number 4, 2020 concerning the Implementation of Education Policies in an 
Emergency the Spread of COVID-19, this was strengthened by circular letter of Secretary General Number 15, 2020 regarding the LFH Implementation Guidelines for COVID-19 emergency. Due to the closure of schools and HEIs in Indonesia, the teaching and learning process has been continued remotely through the use of Information and Communication Technologies (ICT). Electronic learning (elearning) has been identified as the most effective method for continuing the teaching and learning process during the pandemic (Mailizar et al. 2020)

However, not all educational institutions are prepared for the sudden transformation. Some schools may have technology integrated into their regular face-to-face classes. Even so, they are finding it difficult to empower their shareholders in the technology needed for remote online learning and teaching in such a short period of time. Most schools in Indonesia, however, do not have such a privilege in terms of online learning infrastructures. Furthermore, many teachers and lecturers are still inexperienced in using internet techniques of teaching, particularly in diverse parts of Indonesia. (Purwanto, 2020)

Previous research findings have explained some of the challenges and opportunities faced by students while engaging in asynchronous online learning in various parts of the world with various participants, most of whom are teachers or students from universities. It is important to investigate more thoroughly how students' learning experiences in Indonesia differ from past studies, particularly when they use asynchronous online learning program as their learning experience when performing distance learning. Researchers find it interesting to be researched remember that researcher already having the experiences recently. The purpose of this study is divided into two main topics; (1). How do Indonesian vocational high school students perceive asynchronous online English language learning during COVID-19 pandemic? (2). How do Indonesian vocational high school students overcome asynchronous online learning challenges during COVID-19 pandemic?.

\section{LITERATURE REVIEW}

\section{Previous Studies}

There are some previous researches which are relevant to this study. First research from Hariadi et al., (2020) did a research about exploring the experience of EFL students engaged in asynchronous e-learning. The result indicates that the participants have been using technology to support their learning process for quite some time. Regardless, they photographed the assignments, which may be considered a traditional method of completing a task. That statement in line with phenomenon found in related school which has been experienced by the researcher.

The second study by Situmorang et al., (2020) entitled "English Teachers' Preparedness in Technology Enhanced Language Learning during Covid-19 Pandemic" provided students' perceptions about teacher preparedness in asynchronous language learning. The result showed that the students rate their 
teachers highly in the three analyzed areas (digital literacy, digital classroom, and digital assessment), emphasizing the pleasant experiences the students have when learning online. Those findings will be adapted into interviews question in order to enrich how students perceive of asynchronous e-learning in related school.

In other studies, Lestari et al., (2020) conducted a research titled "Students' Self Efficacy in Learning English: A Case Study at a Vocational High School" which offered students perceptions include motivation in learning English. It is could be formulated into how students overcome the challenges faced during asynchronous language learning. The result, based on that research, the enactive mastery experience of students in learning English is the most influential in learning English. Previous English learning experiences provide students the confidence to complete the tasks assigned to them and to reach their goals in learning English.

\section{Online learning, Then vs Now.}

The term of E-learning or electronic learning or online learning is widely used and have various varieties of mediums. Online learning is a form of teaching and learning delivered through the use of digital technology. According to Wentling et al.(2000), online learning is the acquisition and application of knowledge that is transmitted and assisted primarily through electronic methods. The teaching and learning materials presented using this medium have visual, word, animation, video or audio visuals. In addition, it also provides facilities such as classroom learning and assisted by educators in specific fields online. Online learning has always been considered as less interactive than face-to-face learning. It is primarily due to a lack of social presence, social engagement, and student pleasure. Online learning, on the other hand, has been touted as being more cost effective and convenient than traditional educational environments, as well as enabling opportunity for more learners to complete their education (Bali \& Liu 2018). As noted, "Face-to-face lessons with virtual classes and activities" are being integrated in online education, "making time and space more flexible, broadening the teaching and learning spaces that were before practically constrained to the classroom." Ferreira. J, et al (2018).

However, the differences between online learning then and now are kind of similar, but there are a lot of applications that support online learning in Indonesia. Rumah Belajar and SPADA (Sistem Pembelajaran Daring) are the governmentrecommended e-learning platforms in Indonesia. Rumah Belajar is a nonprofit online learning platform created by Indonesia's Ministry of Education and Culture as an alternate learning medium for school teachers and students. SPADA is an elearning platform designed for higher education institutions by the Ministry of Research, Technology, and Higher Education. Furthermore, the Indonesian Ministry of Education and Culture collaborated with MejaKita, Zenius, Cisco Webex, Ganeca Digital, Kelas Pintar, Quipper School and Ruang Guru, among others. All of these materials assist students and teachers in allowing students to learn from home. As result, it helps teachers and students to choose most fit app based on their teaching and learning activity. 


\section{Online Learning in Vocational school}

Basically, in vocational school, the learning is should have knowledge, attitude and skills. However, the process of learning in vocational schools focuses on the development of students' skills and abilities in the workplace. English education is a valuable asset for vocational education students as they prepare to face a variety of obstacles in their work careers (Syakur A.et al. 2020). In this study, researcher focuses on online language learning. The impact of the Covid-19 pandemic on vocational education was that teachers were needed to develop online learning in a very short period of time despite of the course, whereas students were compelled to modify their learning style. On the other hand, not all teachers have the knowledge and experience to create and implement online learning (Syauqi K.et al. 2020). Therefore, this study examines how students' perceptions of vocational school about asynchronous online language learning during COVID-19 pandemic.

\section{Asynchronous Learning}

In our current setting, e-learning is classified into two types: synchronous and asynchronous. Face-to-face communication is the most common type of synchronous communication. However, when distance is taken into account, synchronous communication is still possible through the use of technology or other means. Asynchronous communication, on the other hand, does not occur in real time. Participants in this sort of communication may read and respond at any moment (Lim, 2017). As stated in (Hrastinski, 2008, Chaeruman, 2017) asynchronous e-learning, which is frequently assisted through media such as e-mail and discussion boards, promotes work relationships between learners and teachers even when participants are not online at the same time. Asynchronous e-learning allows students to access an e-learning environment at any time and download materials or communicate with teachers or classmates.

There are also advantages and disadvantages of this kind of learning. As stated in (Nikmah, 2020) some of the benefits of e-learning are that it is more flexible and simpler to access, that it encourages students to communicate with others, and that it is less expensive because students do not need to travel. Otherwise, it has several drawbacks, such as causing learners to experience reflection, detachment, and a lack of interaction or relation. As researcher experiences, there are also likely to be misled into piracy and plagiarism as a result of poor selection skills and the accessibility of copy and paste.

Meanwhile, in this study, related school which being studied already using synchronous and asynchronous online learning. As stated before, this school using synchronous learning less frequent than asynchronous learning. At this school, the headquarters and teachers are agreed to use Google Classroom as tools to learning from home. Thus, Google Classroom is used as the main teaching and learning tools in Vocational school 8 Bekasi. Moreover, Google Classroom was chosen because 
of its ease to access, user-friendly, multi-platforms and free to access with full of its features on it. This supported based on (Maskar, 2019) that Google Classroom was also able to win over students. Google Classroom received positive responses and ratings from students because it was able to make students active to ask questions through the comment column facilities provided. Throughout this case, students who previously felt embarrassed to ask questions in class are now able to simply be facilitated properly by the comment column facilities provided

\section{Students Perceptions in Language Learning}

Perception is the audiovisual impression of being in the world. Perception is a process that someone has gone through in order to develop understanding or sensory knowledge of information that the individual has gotten (Qiong, 2017). One of the most important factors in effective teaching and learning is perception (Bagus et al., 2020). Students' perspectives of language learning are important in creating good and suitable learning experiences for students. Several researchers conducted studies to learn about students' attitudes toward language learning, such as in (Ramírez-Lizcano \& Cabrera-Tovar, 2020, Lasagabaster \& Doiz, 2016). Also they stated that English is one of the most widely spoken languages in the world has influenced students' expectations of language learning experiences and reinforced the view that this language is necessary and beneficial. It is in line with vocational school purpose that aims for abilities in workplace. As previous study, several students stated in their findings that learning English provides them satisfaction, while others believe it has something to do with the things they seek or enjoy. Finally, he stated that students described language learning as something they liked or enjoyed since the experience of learning a new language was appealing regardless of the benefits it could give.

\section{METHOD}

\section{Design and Samples}

The design of this present study was a qualitative exploratory study in order to investigate students' perception on asynchronous online language learning during COVID-19 pandemic. According to Babbie (2010), Exploratory studies are most typically done for three purposes: (1) to satisfy the researcher's curiosity and desire for better understanding, (2) to test the feasibility of undertaking a more extensive study, and (3) to develop the methods to be employed in any subsequent study. It is in line with the aims of this study which is to satisfy the researcher's curiosity and desire for better understanding on phenomenon happen in related school, and beneficial to develop asynchronous online language learning as a reference for the English teachers in related school. Observation and semi-structured interviews was employed to answer the research questions. The researcher using the data of previous observation while having an experience of PLP Program in related school. Meanwhile, interview is used to gain more information from students related to this research. This study will be focus on two Vocational High School students rather 
than group of students in order to gain relevant data according to phenomenon on this research. They will be selected in different majoring class (Accounting and Animation). The reason for choosing them is because they already done asynchronous online learning with the researcher. However, in the sample selection, 1 students of each majoring class will be randomly selected by researcher.

\section{Instrument and Procedure}

The type of qualitative research in this study is basic interpretive research which provides descriptive narratives for understanding a phenomenon by utilizing data acquired in a variety of ways, such as interviews, observations, and document analysis (Ary D, et al,. 2010:29). Based on the statement above, this research will use three instruments, which are observation, interviews and documentation to conduct this qualitative study.

The process of collecting research data will be using observation, interviews and documentation given to 2 participants who have been selected. First of all, the researcher will investigate the phenomena using researcher experience while having PLP program to related school in order to understand and obtain base information about phenomenon discussed, also to makes an interview's questions for next step of collecting data. However, kind of interview used in this study is semi-structured interview. The reason of choosing this kind of interview is make the interview become more flexible in order to obtain rich data that relevant to this study. During the interview, the researcher will record all the process, yet due to the current COVID-19 pandemic situation, the process of collecting data will be held online using zoom, because there is a features that allow user to record the meeting. Researcher also carried out documentation to strengthen the data obtained from interviews.

\section{Data Analysis}

To analyze the data in this study, researcher will be use thematic analysis as data analysis. According to (Braun V., Clarke V., Hayfield N., Terry G. 2019), the technique of analyzing data is divided into six stages, namely: (1) Familiarization with the data, this phase involves reading and re-reading the data, to become immersed and intimately familiar with its content. (2) Coding, after examines data obtained before, researcher will develop the unstructured data into focus data based on research purpose and research question related which are what vocational school students' perceptions and how they overcome with asynchronous online language learning. (3) Generating initial themes, when the researcher discovers scattered codes derived from semi-structured interview results, the researcher organizes the codes into a theme based on needs and is able to answer research questions that the researcher has set earlier. (4) Reviewing themes, after the researcher has formed and carried out the theme, the researcher returns to examine and re-check the previously categorized theme. Ascertain that the overall topic relates to the two research questions that have been developed. The aim of this process is for the 
researcher to determine whether the theme being explored makes sense or even gets in the way of the investigation. Themes that deviate from the research direction do not have to be included. (5) Defining and naming themes, this phase involves developing a detailed study of each theme, as well as determining the scope and focus of each theme. It also involves selecting an informative name for each theme. (6) Writing up, after much examination of data from multiple codes, determining themes, and naming themes, it is now time for researchers to write interpretations of previously examined data. After determining what occurred to the data acquired, it is necessary for the researcher to explain what occurred to the data as well as what the data had to offer.

\section{RESULT AND DISCUSSION}

A total of 2 participants from each majoring class of Accounting and Animation $3^{\text {rd }}$ grade of SMKN 8 Kota Bekasi were volunteered in this research. Findings and discussion are served based on the research question of this study.

Based on the first research question, there are several findings that served below:

Students' perceptions regarding experiences of asynchronous online learning P1: “...materinya nggak masuk ke otak gitu itu kurang efektifjuga."

Also, student with code $\mathrm{P} 2$ said related things:

P2: "Kalau saya sih pas sekolah online sih yang jadi kendalanya paling materinya yang susah dimengerti..."

Based on the research results, students are seems to be know their lacks also ideal method of learning they would prefer in order to be more effectively in learning. This are evidenced through the result of interviews conducted by the researcher. Students said that asynchronous online learning was not quite efficient since they are needs a direct instruction while having a teaching and learning process which is using synchronous online learning.

\section{Students' perceptions regarding English subject learning}

P1: “...kadang ada soal yang harus mendengarkan gitu, kayak listening gitu nanti dikirim audio gitu..."

Meanwhile, student P2 said related things, but has a differences,

P2: “...kebanyakan bentuknya listening sih kak, jadi gurunya ngasih listening gitu terus kita dengerin terus apa-apa yang lagi diomongin kaya dikasih pertanyaannya gitu."

Student P2 also discuss about it before,

P2: “...Apalagi kalau bahasa Inggris kan ada itunya ya Kak ada kayak speakingnya gitu kan itu, jadi kurang kurang terlatih juga kalau misal di sekolah kan ditanya sama Miss nya atau Mrnya pastikan otomatis di sekalian latihan speaking kalau sekolah online jadi kurang gitu kak." 
From their comments, it can be inferred that English subject learned in that school is not including speaking skills, meanwhile it focusing on listening skill as said mostly. In facts, it is true that speaking skill are compatible with their learning media which is Google Classroom, furthermore, it also depends on teacher to find a way to teach such as speaking skill through teaching and learning media that currently in use. Based on Lestari et al., (2020) the enactive mastery experience of students in learning English is the most influential in learning English. It is related to student P2 said that experiencing is really matters that they won't had it while using asynchronously.

\section{Students' perceptions regarding learning media used}

P1: “...gampang dipelajari..."

Also student P2 said:

P2: “...mudah dipahami”

From here, it can be inferred that learning media that they used are user-friendly and simple. Learning media used was already good enough for them to having teaching and learning process.

\section{Students' perceptions regarding material given}

P2: “...kebanyakan PowerPoint sih ka, ada juga yang nerangin nya langsung missal ngejelasinnya lewat video gitu, gurunya bikin video terus videonya di kasih ke kita kita gitu, ..."

From that statement, students are mostly received material in PowerPoint form, however, student P2 finds it flexible because the material given could be read or played repeatedly which in line with Nikmah, (2020).

\section{Students' perception regarding benefits of asynchronous online learning}

P2: “...kalau post kan enaknya kita bisa putar berulang-ulang kalau enggak ngerti atau enggak ngaruh sinyal juga..."

As many benefits of asynchronous online learning, student P2 that the only one said one of the benefits which it was not affected by internet connection speed, and can played repeatedly as in line with previous findings.

\section{Students' perceptions regarding negatives effect of asynchronous online learning. \\ P1: “...kaya makin lama makin bosen aja gitu..." \\ Also student P2 add another impact such as, \\ P2: “...kalau misalnya kita komen Bu ini maksudnya gimana kadang gurunya nggak nggak komen balik gitu kak, maksudnya kalau komunikasi dua arah itu kurang,"}

Based on the findings, there are also drawbacks from learning asynchronously, as related to Arkorful, V., \& Abaidoo, N. (2014), students claim that there is lack of 
interaction or relation between teacher and students. Students P2 said that there are a difficulties when they want to ask about the material given to teacher in Google Classroom, they claim that sometimes teacher won't answer the question.

Based on the second research question, there are several findings that served below:

\section{Students' perceptions regarding how they overcome with difficulties faced} P1: “...diskusi bareng temen."

P1: “...kadang nyari sendiri di google."

Student P2 also has the same act to overcome the difficulties faced like, P2: "kadang kalau misalnya lagi materi bahasa Inggris saya sama teman saya tuh suka chat-an pakai bahasa Inggris gitu kak, apa nggak VN pakai bahasa Inggris itu kalau ngobrol seharian sama temen"

Students on how they overcome problem faced is something interesting to discuss, as related to research conducted by Hariadi et al., (2020) which is as the result of the interviews, student claims to overcome the difficulties faced with their friends, both of participants are likely to discuss privately through other social media, such as: WhatsApp.

\section{Students' suggestion for school regarding current teaching and learning process}

P1: “...kalau misalnya diadain Google meet atau zoom kan jadi berinteraksi secara langsung gitu walaupun virtual..."

Student P2 also has same suggestion like,

P2: “...kaya lebih sering zoom atau google meet gitu..."

P2: “... menurut saya juga nggak papa deh lebih sering Zoom atau gmeet gitu biar lebih masuk juga kalau kan gurunya pasti nerangin gitu kak.”

Their suggestion related to their perceptions about current method of teaching and learning in that school is quite same. They are needs a direct instruction for learning or synchronous online learning in order to understand the material more easily. Also student P2 said:

P2: “...kita juga kadang tahu nih nama gurunya tapi orangnya enggak...”

From here, it can be inferred that students need to know who their teacher was. Communication between teacher and student is more appreciated rather than only giving material in the Google Classroom. However student P1 also said:

P1: “...tapi kalau mungkin ada zoom atau Google meet kayak gitu agak terbebani juga sih"

As statement above it was discussed about internet quota which used to access learning app such as Google Classroom. As said student P1, some of them might be burdened in internet quota if teachers using synchronous online learning app 
such as, Zoom or Google Meet to conduct teaching and learning process. That could be one of the reasons why teachers are not likely to conduct synchronous online learning more often. It is in line with researcher's experiences that written in Report paper of PLP2 Program, which stated that school would not give permission to use another application that burdened their students. As a result the teacher tries their best to not burden their students and still having a good teaching and learning process.

\section{CONCLUSION}

Based on the findings and discussions that has been presented. The researcher can conclude that during asynchronous online learning, students from class of Accounting and Animation of SMKN 8 Kota Bekasi are mostly having difficulties with their learning experiences during Covid-19 pandemic which is dissatisfied with current learning method. The students claim that they are struggles to understand the material given if only using asynchronous online learning. While using asynchronous online learning which is using Google Classroom, they find it difficult to interact or communicate related to material with the teacher, because some of the teacher not replying the comments by the students in Google Classroom, however, they have alternative discussion media which is WhatsApp that used to discuss or communicate between teacher and students or student and student. In other hand, material that seems to be liked by the students is video form, the result stated that beside video form could played repeatedly, it also have similar feels to having a direct instruction from the teachers. Students hope that teaching and learning process could be done effectively and more interactive teaching from teachers in order to improve their skills in English subject.

\section{REFERENCES}

Anderson, T. (2011a). Towards a theory of online learning. In T. Anderson (Ed.), The theory and practice of online learning. 2nd Edition (pp. 45-74). Edmonton: Athabasca University Press.

Arkorful, V., \& Abaidoo, N. (2014) The role of e-learning, the advantages and disadvantages of its adoption in Higher Education. International Journal of Education and Research.

Ary, D., Jacobs, L. C., \& Sorensen, C. K. (2010). Introduction to research in education. Wadsworth, Cangage Learning.

Azhar, K. A., \& Iqbal, N. (2018). Effectiveness of Google Classroom : Teachers' Perceptions. PRIZREN SOCIAL SCIENCE JOURNAL, 2(2), 52-66.

Babbie, E. R. (2010). The practice of social research. Belmont, CA: Wadsworth.

Bagus, I., Pamungkas, A., Brawijaya, U., Adi, S. S., \& Brawijaya, U. (2020). Students' Perception About Improving English Listening Skills Using Movies Among the Vocational High School Students.

Braun V., Clarke V., Hayfield N., Terry G. (2019) Thematic Analysis. In: Liamputtong P. (eds) Handbook of Research Methods in Health Social 
Sciences. Springer, Singapore. https://doi.org/10.1007/978-981-10-52514_103.

Chaeruman, U. A. (2017). PEDATI, Model Desain Sistem Pembelajaran Blended. Direktorat Pembelajaran Kementrian Riset, Teknologi Dan Pendidikan Tinggi.

Ferreira, J., Behrens, M., Torres, P., \& Marriott, R. (2018). The Necessary Knowledge for Online Education: Teaching and Learning to Produce Knowledge. Eurasia Journal of Mathematics, Science and Technology Education, 14(6), 20972106 https://doi.org/10.29333/ejmste/86463.

Hariadi, I. G., \& Simanjuntak, D. C. (2020). Exploring The Experience of EFL Students Engaged in Asynchronous E-Learning. Academic Journal Perspective : Education, Language, and Literature, 8(2), 72. https://doi.org/10.33603/perspective.v8i2.4194.

Hodges, C., Moore, S., Lockee, B., Trust, T., \& Bond, A. (2020). The difference between emergency remote teaching and online learning. Educause Review, 27 March.

Hornby, A S.1995. “Oxford Advenced Learner's Dictionary of Current English". London: Oxford University Press.

Kumar, J. A., Bervell, B. (2019). Google Classroom for mobile learning in higher education: Modelling the initial perceptions of students. Education and Information Technologies, (2).

Lestari, Z. W., Saleh, M., Mujiyanto, J., \& Yusuf, S. (2020). Students' Self Efficacy in Learning English: A Case Study at a Vocational High School. Proceedings of the International Conference on Science and Education and Technology (ISET 2019). doi:10.2991/assehr.k.200620.081.

Lim, Francis Pol. 2017. 'An Analysis of Synchronous and Asynchronous Communication Tools in E-Learning', no. January: 230-34. https://doi.org/10.14257/ast1.2017.143.46

Liu, H. C., \& Chuang, H. H. (2016). Integrating Google Classroom to Teach Writing in Taiwan. Minnesota eLearning Summit.

Mailizar, Almanthari, A., Maulina, S., \& Bruce, S. (2020). Secondary school mathematics teachers' views on e-learning implementation barriers during the Covid-19 pandemic: The case of Indonesia. Eurasia Journal of Mathematics, Science and Technology Education, 16(7), em1860.

Maskar, Sugama. (2019). Persepsi Peserta Didik terhadap Metode Blended Learning dengan Google Classroom. Jurnal Inovasi Matematika. 1.110-121. 10.35438/inomatika.v1i2.156.

Nikmah, K., \& Azimah, N. (2020). A Study of Synchronous and Asynchronous Approaches: Online Arabic Learning During The Covid-19 Pandemic. Alsuna: Journal of Arabic and English Language, 3(2), 115-139. https://doi.org/10.31538/alsuna.v3i2.841.

Nizal, I., Shaharanee, M., Jamil, J. M., Syamimi, S., \& Rodzi, M. (2016). The Application of Google Classroom as a Tool for Teaching and Learning. Journal of Telecommunication, Electronic and Computer Engineering, 8(10), $5-8$. 
Papadima-Sophocleous, S., \& Loizides, F. (2016). Exploring the benefits and disadvantages of introducing synchronous to asynchronous online technologies to facilitate flexibility in learning. In S. Papadima-Sophocleous, L. Bradley, \& S. Thouësny (Eds), CALL communities and culture - short papers from EUROCALL 2016 (pp. 363-368).

Pollard, A. (2008). Reflective Teaching: Evidence-informed Professional Practice (3rd ed.). London: Continuum International Publishing Group.

Purwanto, A. et al(2020). Studi Eksploratif Dampak Pandemi COVID-19 Terhadap

Proses Pembelajaran Online di Sekolah Dasar. EduPsyCouns: Journal of Education, Psychology and Counseling, 2(1), 1-12.

Ramírez-Lizcano, N., \& Cabrera-Tovar, M.A. (2020). EFL Learners' Perceptions about Language Learning and Culture When Using Telecollaboration. Profile Issues in Teachers' Professional Development, 22, 95-113.

Rampal, L. \& Boon Seng, L. (2020). Coronavirus disease (COVID-19) pandemic. Med J Malaysia Vol. 75, No 2 March 2020.

Situmorang, Komilie, Nugroho, D.Y., Pramusita, S.M. (2020). English Teachers' Preparedness in Technology Enhanced Language Learning During Covid-19 Pandemic - Students' Voice. Jo-ELT (Journal of English Language Teaching) Fakultas Pendidikan Bahasa \& Seni Prodi Pendidikan Bahasa Inggris IKIP. https://doi.org /10.33394/jo-elt.v7i2.2973.

Syakur, A., Zainuddin, H. M., \& Hasan, M. A. (2020). Needs Analysis English For Specific Purposes (ESP) For Vocational Pharmacy Students. Budapest International Research and Critics in Linguistics and Education (BirLE) Journal, 3(2), 724-733.

Syauqi, K., Munadi, S., \& Triyono, M. B. (2020). Students' perceptions toward vocational education on online learning during the COVID-19 pandemic. International Journal of Evaluation and Research in Education (IJERE), 9(4), 881.

Toquero, C. M. (2020). Challenges and opportunities for higher education amid the COVID-19 pandemic: The Philippine context. Pedagogical Research, 5(4). World Health Organization Covid 19 Infection. (2020).

Yang, Y., \& Cornelius, L.F. (2004). Students' Perceptions towards the Quality of Online Education: A Qualitative Approach.

Yuhanna, I., Alexander, A., \& Kachik, A. . (2020). Advantages and disadvantages of Online Learning. Journal Educational Verkenning, 1(2), 13-19. https://doi.org/10.48173/jev.v1i2.54 